CLINICAL STUDY

\title{
Distribution of strontium and mineralization in iliac bone biopsies from osteoporotic women treated long-term with strontium ranelate
}

\author{
Audrey Doublier ${ }^{1,2}$, Delphine Farlay ${ }^{1,2}$, Mohamed T Khebbab ${ }^{3}$, Xavier Jaurand ${ }^{3}$, Pierre J Meunier ${ }^{1,2}$ \\ and Georges Boivin ${ }^{1,2}$ \\ ${ }^{1}$ INSERM, UMR1033, Team Bone Quality and Biological Markers, F-69372 Lyon, France, ${ }^{2}$ Université de Lyon, F-69008 Lyon, France and ${ }^{3}$ Centre \\ Technologique des Microstructures, Université de Lyon, F-69100 Villeurbanne, France
}

(Correspondence should be addressed to A Doublier who is now at INSERM, UMR 1033, Université de Lyon, Faculté de Médecine Lyon-Est; Email: audrey.doublier@inserm.fr)

\begin{abstract}
Objective: To investigate interactions between strontium $(\mathrm{Sr})$ and bone mineral and its effects on mineralization in osteoporotic women treated long-term with Sr ranelate (SrRan).

Design: In this study, 34 iliac bone biopsies were analyzed after 2, 12, 24, 36, 48, and 60 months of treatment with SrRan.

Methods: Sr global distribution was analyzed by X-ray cartography and the percentage of bone area containing Sr was calculated in the bone samples. The focal distribution of $\mathrm{Sr}$ in all bone samples was investigated by X-ray microanalysis. The degree of mineralization was assessed by quantitative microradiography.

Results: Absent from old bone formed before the beginning of treatment, Sr was exclusively present in bone formed during this treatment with a much higher focal Sr content in new bone structural units than in old ones. A progressive increase in the extent of areas containing Sr was observed during treatment. The focal bone Sr content in recently formed bone was constant over treatment. Secondary mineralization was maintained at a normal level during treatment.

Conclusion: Thus, the quality of bone mineralization (density and heterogeneity at tissue level) was preserved after a long-term treatment with SrRan.

European Journal of Endocrinology 165 469-476
\end{abstract}

\section{Introduction}

Strontium ranelate (SrRan) is an effective antiosteoporotic drug developed for the treatment of postmenopausal osteoporosis (PMOP). In vitro and in vivo experimental studies (1-9) demonstrate that SrRan has a unique dissociating effect on bone remodeling by maintaining bone formation and decreasing bone resorption, resulting in a prevention of bone loss and an increase in bone mass and strength (9-13). In clinical studies, Sr provides early and sustained vertebral and nonvertebral (including hip) antifracture efficacy and increases the bone mineral density at the spine and hip levels (14-18). Human studies also show an improvement of microarchitecture under SrRan treatment (19-21).

The rate of bone remodeling and the mean duration of secondary mineralization of bone influence the degree of mineralization of bone (DMB) (22-26). When bone remodeling rate increases, the birthrate of new bone structural units (BSUs) increases, resulting in less time to complete secondary mineralization and, ultimately, DMB decreases. This is observed with anabolic agents used to treat osteoporosis such as parathyroid hormone $(27,28)$. Conversely, when bone remodeling rate is decreased (treatment with antiresorptive agents such as bisphosphonates, selective estrogen receptor modulators, or estrogens), the birthrate of BSUs is greatly decreased, their lifespan increases, the duration of secondary mineralization is greatly increased, and the DMB increases (23, 25, 29-31).

In a recent study on PMOP women treated for 36 months with SrRan, we have shown that $\mathrm{Sr}$ was exclusively present in bone formed during treatment and was heterogeneously distributed with higher focal concentrations in recent bone formed during treatment than in old bone formed before the beginning of treatment (32). The X-ray cartography, illustrating the extent of bone areas containing $\mathrm{Sr}$ and thus the formation activity of Sr during treatment, showed an increase in bone areas containing Sr until 36 months, more in cancellous than in cortical bone (32). Secondary mineralization was maintained at a normal level during the treatment (32). These observations 
confirmed the previous ones in monkeys receiving SrRan for 13 weeks (33) and 52 weeks (34). However, the incorporation of $\mathrm{Sr}$ within the apatite crystals represented a maximum of one calcium (Ca) ion over ten substituted by one Sr ion in monkeys $(33,34)$ and a maximum of $0.5 \mathrm{Sr}$ ion in women $(35,36)$.

We hypothesize that even after a long-term treatment (up to 60 months) and whatever the distribution of $\mathrm{Sr}$ in bone, quality of bone mineralization (DMB and the heterogeneity index (HI)) is maintained at tissue level. Thus, in iliac bone biopsies taken from PMOP women after a prolonged treatment with SrRan, the main objectives of this study were to assess i) the global distribution of $\mathrm{Sr}, \mathrm{Ca}$, and phosphorus elements in both cortical and cancellous bone tissue on all the area of the biopsy; ii) the focal bone contents of $\mathrm{Sr}$, Ca, and phosphorus in bone formed before and during treatment in cortical and cancellous tissues; and iii) the level of the secondary mineralization of bone.

\section{Materials and methods}

\section{Patients and iliac bone samples}

Transiliac bone biopsies were obtained from PMOP women (72 \pm 5 years) enrolled in three randomized, double-blinded, placebo-controlled clinical trials, STRATOS (16), SOTI (14), and TROPOS (17). The main biopsies analyzed were obtained after $36(n=17), 48$ $(n=7)$, and $60(n=7)$ months of treatment with 2 g/day of SrRan (Protelos - Protos - Protaxos - Osseor - Bivalos, Servier, Suresnes, France). All the patients also received daily Ca (up to $1000 \mathrm{mg}$ ) and vitamin D (up to $800 \mathrm{UI}$ ) according to their needs. Before biopsy, patients received $1 \mathrm{~g}$ /day tetracycline for 2 days, followed by a 10-day tetracycline-free interval, and then received $1 \mathrm{~g}$ /day tetracycline for two other days. Biopsies were performed within 5-7 days of the last dose of tetracycline (19).

Bone samples were fixed in 70\% alcohol, dehydrated in absolute alcohol, and then embedded in methyl methacrylate without prior decalcification (32). The global cartography (a very time-consuming method) was performed on ten biopsies taken after $2(n=1), 12$ $(n=1), 24(n=1), 36(n=4), 48(n=2)$, and 60 months $(n=1)$ of treatment. All bone samples were used for focal X-ray microanalysis and quantitative microradiography. The biopsies taken at 36 months of treatment, previously partly published (32), were included in this study to show a global evolution until 60 months of treatment.

The samples presented in this study were blindselected by Servier among samples allowing a global study of the entire bone core. These bone samples have been analyzed by histomorphometry and also showed increased mineral apposition rate (MAR) and osteoblastic surfaces (19).

\section{Cartography by global X-ray microanalysis}

For the X-ray cartography, the ten embedded bone samples were surfaced with an alumina suspension ( $1 \mu \mathrm{m})$, carbon-coated, and then fixed in the specimen holder (32).

Global X-ray microanalysis was performed using a Camebax electron microprobe (Cameca, Gennevilliers, France) equipped with an energy-dispersive X-ray spectrometer Kevex Super Quantum Mark 5 (Kevex Instruments, Valencia, CA, USA), coupled with the analysis system Noran Voyager III (Noran Instruments, Middletown, WI, USA). Sr L $\alpha, \mathrm{P} \mathrm{K} \alpha$, and Ca K $\alpha$ were the main elements analyzed on the same whole area of bone samples, including osteons and packets formed before and during treatment, on a thickness of $1 \mu \mathrm{m}$. Secondary electron images (morphology of the area measured) and X-ray images (topographical distribution of the main elements analyzed) were performed for each biopsy at a voltage of $15 \mathrm{kV}$, which was the lowest allowing the analysis of the main elements constituting bone mineral without destroying the sample. The resolution chosen for cartography was $256 \times 256$ pixels and the counting time for each pixel was $0.07 \mathrm{~s}$, allowing duration of acquisition of $90 \mathrm{~min}$ for each region of interest $\left(1 \mathrm{~mm}^{2}\right)$. This was the largest area analyzable at the lowest magnification of $\times 100$ and preserving an overlapping band allowing the mapping of the complete image of the bone sample. To perform one cartography, a large number of acquisitions and a precise reconstruction were necessary for each sample.

The quantitative image analysis of the cartography required i) the manual elimination of pixels due to background noise, ii) the binarization and dilatation allowing the obtaining of continuous areas, and iii) the calculation of the percentage of bone area, where $\mathrm{Sr}$ is present, relative to the total analyzed bone area delimited by the presence of $\mathrm{Ca}$. The percentage of the analyzed bone area containing $\mathrm{Sr}$ (number of pixels of $\mathrm{Sr}$ over number of pixels of $\mathrm{Ca}$ ) was calculated for cortical, cancellous, and total (cortical + cancellous) bone tissues.

\section{Focal X-ray microanalysis}

The embedded bone samples were surfaced with an alumina suspension $(1 \mu \mathrm{m})$, carbon-coated, and then fixed into the specimen holder (32). The focal measurements were performed on $1 \mu \mathrm{m}^{2}$ areas. These analyzed areas included old bone formed before treatment and recent bone formed during treatment from both cortical and cancellous bone. Bone was considered as recent if osteons or endosteal borders were not covered by other BSUs, when there is a large haversian canal, or in the border of trabeculae. Old bone corresponded to interstitial cortical bone and to the center of trabeculae. In each category of tissue, 15 different measurements were performed (15 in 
(a)

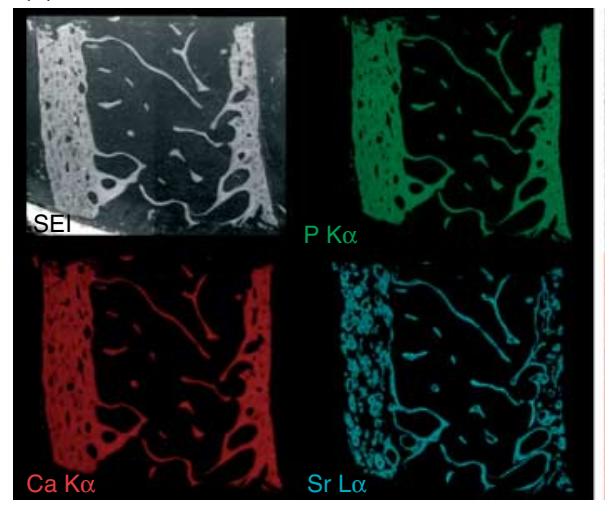

(b)

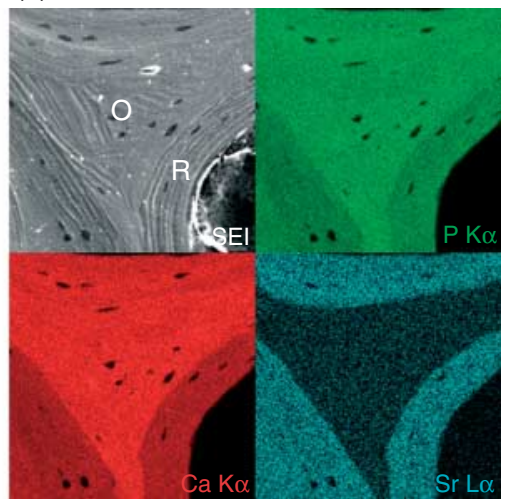

Figure 1 Global (a) and focal (b) distribution (or cartography) of phosphorus (P K $\alpha$ ), calcium $(\mathrm{Ca} K \alpha)$, and strontium $(\mathrm{Sr} L \alpha)$ from a PMOP woman treated with $2 \mathrm{~g} /$ day SrRan for 60 months. The secondary electron image (SEI) gave the global topography of the area analyzed and allowed the discrimination between recent $(R)$ and old (O) bone. The distribution of elements reflected the formation activity of the treatment. Strontium was only present in recent bone $(R)$ formed under treatment, and the BSUs containing $\mathrm{Sr}$ also contained less phosphorus and calcium elements. recently formed and 15 in old cortical bone, 15 in recently formed, and 15 in old cancellous bone), i.e. a total of 60 measurements in each bone sample. Recent bone formed during treatment was separated from old bone based on morphological criteria.

Focal X-ray microanalysis was performed using the same equipment previously mentioned for X-ray cartography. Sr $L \alpha, P K \alpha$, and Ca K $\alpha$ were the main elements analyzed at the same place at a voltage of $15 \mathrm{kV}$. Each measurement represented a count of $100 \mathrm{~s}$ at the same place. For each element, contents were expressed as weight and atomic percentages $(100 \%$ corresponding to the total elements analyzed, i.e. Ca, phosphorus, Sr, magnesium, sodium, and oxygen). Finally, the weight and atomic ratios $\mathrm{Ca} / \mathrm{P}, \mathrm{Ca}+\mathrm{Sr} / \mathrm{P}$, $\mathrm{Sr} / \mathrm{Ca}, \mathrm{Sr} / \mathrm{P}$, and $\mathrm{Sr} / \mathrm{Ca}+\mathrm{Sr}$ were also calculated. Secondary electron images and X-ray images were performed to illustrate the focal $\mathrm{Sr}$ distribution in bone tissue.

\section{Quantitative microradiography}

Thick sections (about $150 \mu \mathrm{m}$ ) were cut from the bone samples used for the focal X-ray microanalysis using a precision diamond wire saw (Well, Escil, Chassieu, France) and were progressively ground to a thickness of $100 \mu \mathrm{m}$ and polished with an alumina suspension $(1 \mu \mathrm{m})$. The thickness of the section was measured with an accuracy of $1 \mu \mathrm{m}$ using a precision micrometer (Compac, Geneva, Switzerland). Bone sections were then cleaned with ultrasounds and microradiographed $(23,26)$.

Microradiography was performed using a PW 1830/40 X-ray diffraction unit equipped with a PW 2273/20 diffraction tube (Philips, Limeil-Brévannes, France). The nickel-filtered copper $\mathrm{K} \alpha$ radiation was used under $25 \mathrm{kV}$ and $25 \mathrm{~mA}$. A Geola high-resolution film (Slavich International Wholesale Office, Vilnius, Lithuania) was exposed for $20 \mathrm{~min}$ simultaneously with the entire $100 \mu \mathrm{m}$-thick section and the aluminum standard. For quantitative evaluation of X-ray absorption by the bone section, a calibration reference system composed of aluminum step-wedge was exposed on each microradiograph $(23,26)$. Automatic programs (MorphoExpert and Mineralization) were used to analyze gray levels of the aluminum standard (Explora Nova, La Rochelle, France). A digital camera (actual resolution: $1600 \times 1200$ pixels or $800 \times 600$ after binning) captured the microscopic image of the microradiograph. After calibration using the aluminum reference system, the measured region of bone tissue was automatically selected and then the gray levels were segmented after bone threshold. Subsequently, the values of the gray levels obtained at the pixel level (size $2.82 \mu \mathrm{m}$ at a magnification of $\times 2.5$ ) were converted into values of mineralization after plotting a calibration curve based on the values obtained from the aluminum standard. Finally, the variables reflecting the secondary mineralization were expressed in grams of mineral per cubic centimeter of bone tissue. Results were measured separately in cortical, cancellous, and total (cortical+ cancellous) bone tissues. The main variable measured

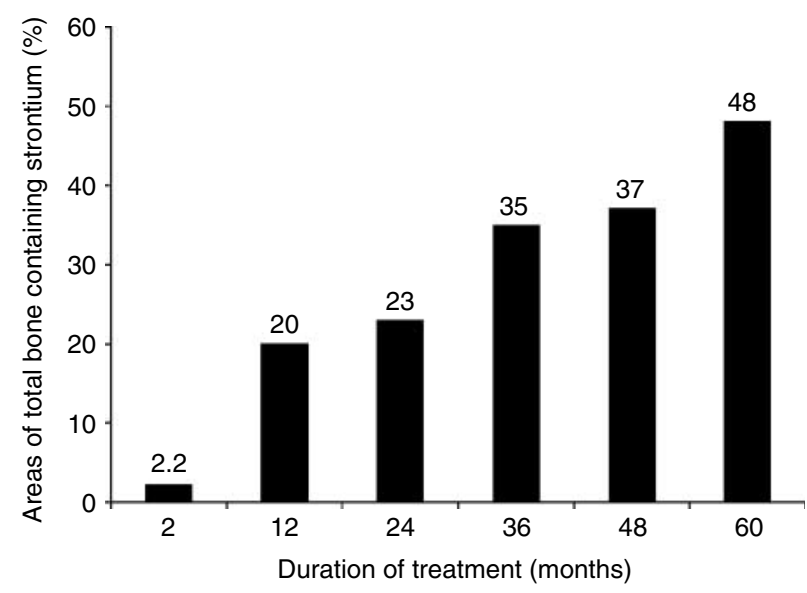

Figure 2 Evolution of the global distribution of strontium in total (cortical+cancellous) bone (\%) according to the duration of treatment. There was a progressive extension of bone areas containing strontium. 
for each sample was the mean DMB, and the heterogeneity of the distribution of the DMB, calculated as the width at half-maximum of the curve $(23,26)$. However, a limitation of this technique was the underestimation of $\mathrm{DMB}$ in a few measurements of trabecular bone, related to the partial filled volume effect. However, this error in measurement slightly influences the global results because it is comparable in all groups.

\section{Statistical analysis}

Results were expressed as mean \pm s.D. Owing to the small number of patients in each group, nonparametric tests were used: the Kruskal-Wallis test was performed to analyze the effect of time. The Mann-Whitney $U$ test was used for the comparison of means between groups. Correlations between two parameters were tested with the Spearman test. Significant difference was accepted for $P \leq 0.05$.

\section{Results}

\section{Global distribution of Sr in bone tissue}

In SrRan-treated PMOP patients, Sr was only detected at the mineral substance level. Indeed, Sr was detected neither in the uncalcified organic matrix (osteoid tissue) nor in the marrow and/or bone cells.

The X-ray cartography allowed the visualization of the BSUs containing Sr, Ca, and phosphorus (Fig. 1a). In cortical and cancellous bone, Sr was always heterogeneously distributed and almost exclusively present in the recent bone formed during treatment compared with old bone formed before the beginning of treatment (Fig. 1b). The osteons and packets containing $\mathrm{Sr}$ corresponded to BSUs involved in formation activity during a part of the period of treatment but not necessarily during all the duration of the treatment. Old interstitial bone did not contain Sr. BSUs containing Sr (formed under treatment) also contained less Ca and phosphorus than old interstitial bone (Fig. 1b).

Table 1 Focal X-ray microanalysis of the major elements contained in recent (formed during treatment) and old (formed before treatment) bone tissues from cortical and cancellous bone, as weight \%, from patients treated with $2 \mathrm{~g} /$ day of SrRan. Sr was almost always absent in old bone and was present in recent bone. The focal bone Sr content in recent bone was constant from 2 to 60 months of treatment.

\begin{tabular}{|c|c|c|c|c|c|c|c|c|}
\hline $\begin{array}{l}\text { Treatment } \\
\text { (months) }\end{array}$ & $n$ & Bone & $\begin{array}{c}\mathbf{P} \\
\text { (weight \%) }\end{array}$ & $\begin{array}{c}\text { Ca } \\
\text { (weight \%) }\end{array}$ & $\begin{array}{c}\mathbf{S r} \\
\text { (weight \%) }\end{array}$ & $\mathrm{Ca} / \mathrm{P}$ & $\mathrm{Ca}+\mathrm{Sr} / \mathrm{P}$ & $\mathrm{Sr} / \mathrm{Ca}+\mathrm{Sr}$ \\
\hline & & Cortical & & & & & & \\
\hline & & Recent & $13.79(0.70)$ & 33.78 (1.91) & 1.59 & $2.45(0.08)$ & $2.46(0.07)$ & $0.003(0.013)$ \\
\hline \multirow[t]{3}{*}{2} & 1 & $\begin{array}{l}\text { Old } \\
\text { Cancellous }\end{array}$ & $13.66(0.31)$ & $34.22(0.97)$ & $0.00(0.00)$ & $2.51(0.06)$ & $2.51(0.06)$ & $0.000(0.000)$ \\
\hline & & Recent & $13.65(0.49)$ & 32.09 (1.22) & $1.81(0.27)$ & $2.35(0.10)$ & $2.40(0.07)$ & $0.018(0.027)$ \\
\hline & & Old & $13.84(0.51)$ & $34.54(1.66)$ & $0.00(0.00)$ & $2.49(0.07)$ & $2.49(0.07)$ & $0.000(0.000)$ \\
\hline \multirow[t]{5}{*}{12} & 1 & Cortical & & & & & & \\
\hline & & Recent & $13.39(0.71)$ & $32.37(1.71)$ & $1.42(0.27)$ & $2.42(0.08)$ & $2.52(0.07)$ & $0.042(0.008)$ \\
\hline & & Old & $13.39(0.73)$ & $34.40(1.97)$ & $0.00(0.00)$ & $2.57(0.04)$ & $2.57(0.04)$ & $0.000(0.000)$ \\
\hline & & Recent & $13.88(0.97)$ & 32.95 (1.99) & $1.25(0.36)$ & $2.38(0.08)$ & $2.47(0.08)$ & $0.036(0.010)$ \\
\hline & & Old & $13.66(0.77)$ & $34.75(2.14)$ & $0.00(0.00)$ & $2.54(0.06)$ & $2.54(0.06)$ & $0.000(0.000)$ \\
\hline \multirow[t]{6}{*}{24} & 1 & Cortical & & & & & & \\
\hline & & Recent & $14.72(0.96)$ & 37.22 (3.65) & $2.18(0.29)$ & $2.52(0.12)$ & $2.67(0.12)$ & $0.056(0.007)$ \\
\hline & & Old & $13.99(0.85)$ & $35.91(2.84)$ & $0.01(0.04)$ & $2.57(0.10)$ & $2.57(0.10)$ & $0.000(0.001)$ \\
\hline & & Cancellous & & & & & & \\
\hline & & Recent & $13.75(1.13)$ & 34.32 (3.03) & $2.23(0.39)$ & $2.50(0.07)$ & $2.66(0.07)$ & $0.061(0.009)$ \\
\hline & & Old & $14.20(1.14)$ & 37.35 (3.37) & $0.03(0.07)$ & $2.63(0.08)$ & $2.63(0.08)$ & $0.001(0.002)$ \\
\hline \multirow[t]{6}{*}{36} & 17 & Cortical & & & & & & \\
\hline & & Recent & $15.04(0.85)$ & 36.84 (3.08) & $1.74(0.95)$ & $2.45(0.14)$ & $2.57(0.14)$ & $0.045(0.024)$ \\
\hline & & Old & $15.03(0.79)$ & $39.04(3.21)$ & $0.00(0.04)$ & $2.60(0.13)$ & $2.60(0.13)$ & $0.000(0.001)$ \\
\hline & & Cancellous & & & & & & \\
\hline & & Recent & $14.97(0.95)$ & 36.09 (3.12) & $1.73(0.89)$ & $2.41(0.13)$ & $2.53(0.13)$ & $0.046(0.023)$ \\
\hline & & Old & $15.14(0.86)$ & 38.52 (3.22) & $0.00(0.03)$ & $2.54(0.11)$ & $2.52(0.26)$ & $0.000(0.001)$ \\
\hline \multirow[t]{6}{*}{48} & 7 & Cortical & & & & & & \\
\hline & & Recent & $13.99(0.98)$ & 32.28 (2.83) & $1.57(0.61)$ & $2.31(0.08)$ & $2.42(0.09)$ & $0.046(0.018)$ \\
\hline & & Old & $13.88(0.74)$ & $34.29(2.25)$ & $0.00(0.02)$ & $2.47(0.07)$ & $2.47(0.07)$ & $0.000(0.001)$ \\
\hline & & Cancellous & & & & & & \\
\hline & & Recent & $13.90(0.77)$ & $31.24(1.95)$ & $1.55(0.65)$ & $2.25(0.09)$ & $2.36(0.09)$ & $0.047(0.020)$ \\
\hline & & Old & $14.04(0.70)$ & 34.01 (2.04) & $0.03(0.18)$ & $2.42(0.07)$ & $2.42(0.07)$ & $0.001(0.005)$ \\
\hline \multirow[t]{6}{*}{60} & 7 & Cortical & & & & & & \\
\hline & & Recent & $14.43(1.39)$ & $33.42(3.13)$ & $1.44(0.97)$ & $2.32(0.11)$ & $2.42(0.09)$ & $0.041(0.024)$ \\
\hline & & Old & $14.17(1.24)$ & $34.76(3.26)$ & $0.04(0.16)$ & $2.45(0.08)$ & $2.46(0.08)$ & $0.001(0.004)$ \\
\hline & & Cancellous & & & & & & \\
\hline & & Recent & $14.95(1.68)$ & $34.14(4.19)$ & $1.37(0.79)$ & $2.28(0.11)$ & $2.37(0.10)$ & $0.038(0.019)$ \\
\hline & & Old & 14.85 (1.69) & $35.91(4.18)$ & $0.06(0.23)$ & $2.42(0.09)$ & $2.42(0.08)$ & $0.002(0.007)$ \\
\hline
\end{tabular}


The X-ray cartography revealed that $\mathrm{Sr}$ was distributed and was present up to $48 \%$ of the total bone area $(27.53 \pm 16.02 \%$, mean \pm s.D. from all data). Whatever the duration of treatment, the percentage of bone area with $\mathrm{Sr}$ was higher in cancellous bone $(36.25 \pm 28.52 \%)$ than in cortical bone $(24.70$ $\pm 15.34 \%)$. The global distribution of Sr showed, in a small number of samples, a regular and progressive extension of the areas containing Sr from 2 months (2\%) until 36 months (35\%), to finally reach a value of $48 \%$ at 60 months (Fig. 2).

\section{Focal contents of elements measured in bone tissue}

Sr was absent from bone formed before the beginning of treatment and was almost exclusively present in recent bone formed during treatment (Table 1, Fig. 3) as evidenced by tetracycline double labeling. The focal Sr content measured in total bone was constant whatever the duration of treatment (Fig. 3) and showed similar evolutions in cortical and cancellous bone (Table 1). In total bone, the focal content of Sr in bone formed during treatment reached early a content close to the one measured after 48-60 months of treatment (Table 1, Fig. 3). Indeed, the BSUs containing $\mathrm{Sr}$ revealed mean Sr contents not significantly $(P=0.81)$ different between 2, 12, 24, 36, 48, and 60 months. After 36 months of treatment, $\mathrm{Ca}, \mathrm{Ca} / \mathrm{P}$, and $\mathrm{Ca}+\mathrm{Sr} / \mathrm{P}$ were significantly lower $(P \leq 0.01)$ in recent bone formed during the treatment than in old bone formed before treatment initiation. In recent bone, the $\mathrm{Sr} /$ $\mathrm{Ca}+\mathrm{Sr}$ ratio showed a replacement of $\mathrm{Ca}$ ions by $\mathrm{Sr}$ ions from 0 to $6 \%$ (Table 1 ). In old bone, the $\mathrm{Sr} / \mathrm{Ca}+\mathrm{Sr}$ ratio was always zero.

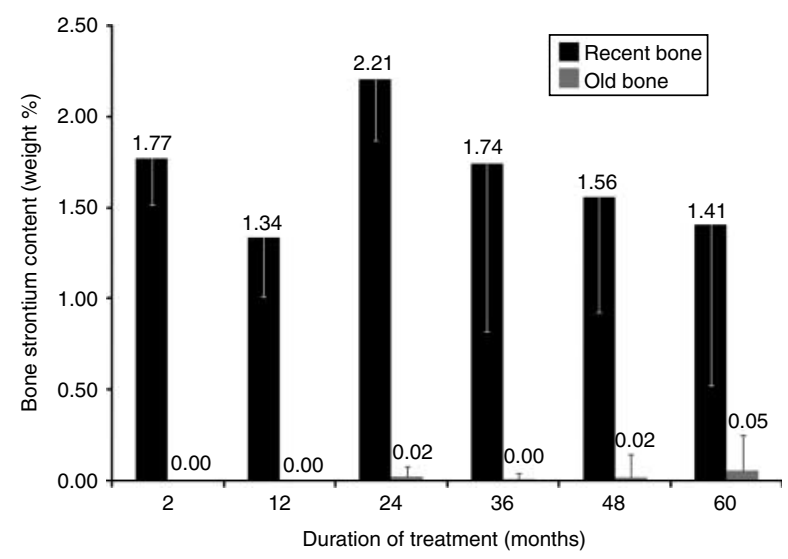

Figure 3 Evolution of the focal bone strontium content in total (cortical + cancellous) bone (weight \%) according to the duration of treatment. Strontium was almost always absent in old interstitial bone formed before the initiation of treatment. In recent bone formed during treatment, the focal strontium content was constant all along the duration of treatment.
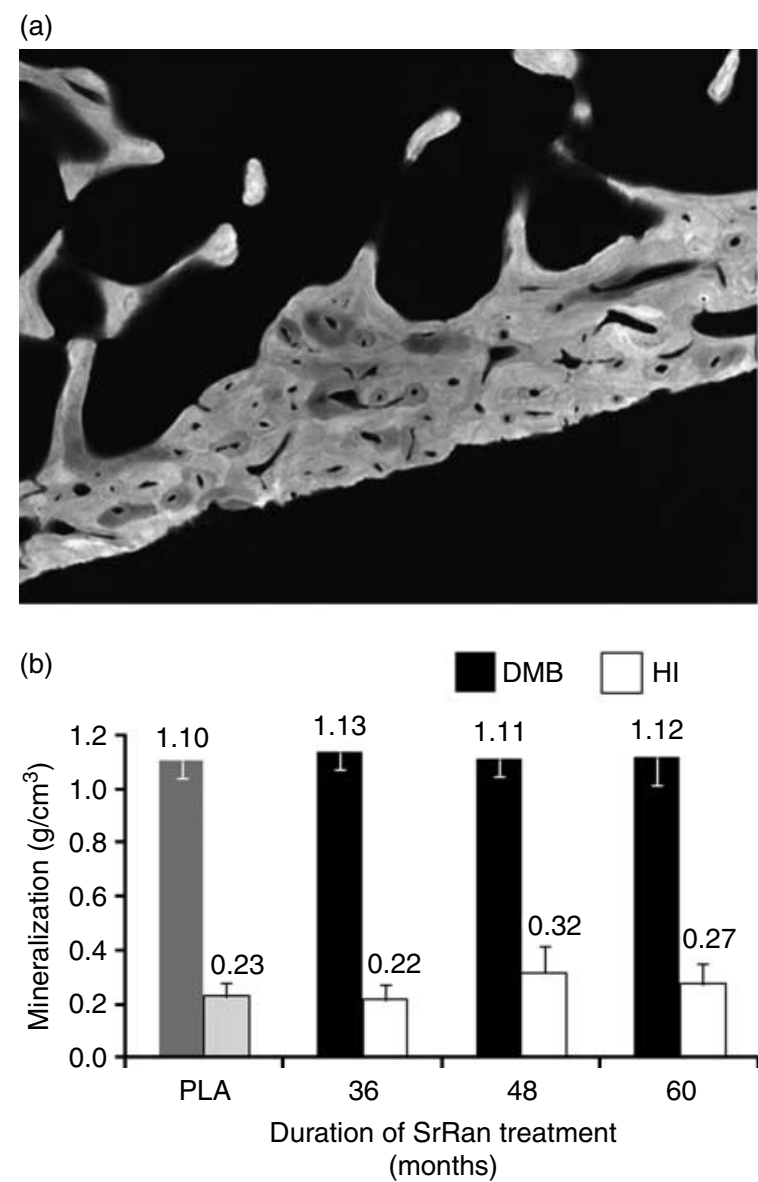

Figure 4 Microradiograph (a) illustrating the heterogeneity of the secondary mineralization from a PMOP woman treated with $2 \mathrm{~g} /$ day of SrRan for 48 months and (b) evolution of the degree of mineralization of bone (DMB, black bars) and of the heterogeneity index (HI, white bars) of total (cortical + cancellous) bone according to the duration of SrRan treatment compared with DMB and $\mathrm{HI}$ measured in patients treated with placebo (PLA, dark and light gray bars respectively) during 36 months (31). DMB and $\mathrm{HI}$ remained constant whatever the duration of treatment.

\section{Secondary mineralization of bone}

Up to 60 months of treatment, DMB, reflecting the secondary mineralization of bone, remained constant in cortical $(1.12 \pm 0.08)$, cancellous $(1.13 \pm 0.07)$, or total bone $(1.13 \pm 0.07)$. The HI (of the distribution of DMB) was constantly heterogenous with a mean of 0.25 \pm 0.08 in total bone (Fig. 4, Table 2).

\section{Discussion}

To assess the impact of Sr on bone mineralization even after a long-term treatment, we found in this study that i) Sr was heterogeneously distributed in bone tissue and was exclusively present in bone formed after the beginning of treatment; ii) bone area containing $\mathrm{Sr}$ increased until 60 months of treatment; iii) the extent of 
Table 2 Variables reflecting the secondary mineralization (DMB) and (HI) measured in cortical and cancellous bone of patients treated daily with $2 \mathrm{~g}$ of SrRan. These variables were constant whatever the duration of treatment. Range corresponds to the lowest and the highest values.

\begin{tabular}{lclrr}
\hline & & & \multicolumn{2}{c}{$\begin{array}{c}\text { Secondary mineralization } \\
\text { mean }(\mathrm{s} . \mathrm{D} .) / \text { range }\end{array}$} \\
\cline { 4 - 5 } $\begin{array}{l}\text { Treatment } \\
\text { (months) }\end{array}$ & $\boldsymbol{n}$ & Bone & $\mathrm{DMB}\left(\mathrm{g} / \mathrm{cm}^{3}\right)$ & $\mathrm{HI}\left(\mathrm{g} / \mathrm{cm}^{3}\right)$ \\
\hline 36 & 17 & Cortical & $1.13(0.07) /$ & $0.21(0.07) /$ \\
& & Cancellous & $1.00-1.24$ & $0.11-0.32$ \\
& & & $1.04-1.25$ & $0.21(0.06) /$ \\
48 & 7 & Cortical & $1.11(0.09) /$ & $0.13-0.32(0.14) /$ \\
& & & $1.01-1.23$ & $0.14-0.58$ \\
& & Cancellous & $1.12(0.05) /$ & $0.24(0.07) /$ \\
60 & & & $1.05-1.20$ & $0.16-0.40$ \\
& 7 & Cortical & $1.12(0.11) /$ & $0.27(0.08) /$ \\
& & & $0.96-1.31$ & $0.15-0.36$ \\
& & Cancellous & $1.11(0.09) /$ & $0.28(0.07) /$ \\
& & & $0.99-1.29$ & $0.17-0.41$ \\
\hline
\end{tabular}

areas containing Sr was often higher in cancellous than in cortical bone; iv) the focal Sr content was constant in bone formed during treatment; and v) whatever the duration of treatment and the content of Sr in bone, the secondary mineralization was maintained at a normal level.

\section{Distribution of $\mathrm{Sr}$ in bone}

Sr was taken up by bone mineral and heterogeneously distributed. Owing to tetracycline double-labeling, we were able to identify bone formed under treatment and we could observe that $\mathrm{Sr}$ was almost exclusively present in the bone formed under treatment (32). BSUs containing Sr were more numerous in cancellous than in cortical bone. This was probably explained by the fact that cancellous bone is richer in new bone than cortical bone, due to a higher remodeling rate or to greater surface-to-volume ratio in cancellous tissue (25). The global distributions of Sr observed in this study were in good agreement with those already reported in monkeys $(33,34)$ and in women (32). Nevertheless, focal Sr contents in areas containing Sr were similar after 2-60 months of treatment, i.e. that for a given patient, and independent of the duration of treatment, bone Sr uptake was constant without progressive enrichment at the same site. The evolution of the global bone Sr content measured chemically (32) was thus due to extended bone area containing $\mathrm{Sr}$ but not to its focal accumulation. The observation of a limited number of cartographies of Sr showed an increment in the number of BSUs having had a formation activity during a part of the treatment. During the 60 months of treatment, a large part of the old interstitial bone did not contain Sr. Finally, in the same patients, the relative change in lumbar spine bone mineral density from baseline followed the same evolution than that of total iliac bone areas containing Sr (data not shown).

\section{Quantification of Sr in bone}

Focal bone $\mathrm{Sr}$ content in old bone formed before treatment was very low, if not zero, and similar to the amount of Sr reported in the iliac bone from placebotreated PMOP patients, in old bone of patients treated for 36 months with SrRan (32), and from healthy subjects or untreated osteoporotic patients (37). After 2-60 months of treatment with SrRan in PMOP women, about the same amount of $\mathrm{Sr}$ was taken up by bone tissue $(1.59 \pm 0.70$ weight $\%$, mean \pm s.D. of all time points) and was almost exclusively present in recent bone formed during treatment. This strongly suggested that Sr was taken up early by bone mineral and/or with the same ratio ( $\mathrm{Sr}$ vs $\mathrm{Ca}$ ) whatever the duration of treatment. Moreover, the small variations of focal Sr content in recent bone (Fig. 3) can be explained by the variations in blood Sr levels because there was a significant positive correlation $(P=0.0017)$ between these two parameters. The $\mathrm{Sr} / \mathrm{Ca}+\mathrm{Sr}$ ratio is the most relevant to define how many $\mathrm{Ca}$ atoms were replaced by Sr atoms. Our data showed that the replacement of Ca by $\mathrm{Sr}$ was between 0 and $6 \%$. These results are in the same order of magnitude than data recently published $(35,36)$ and confirmed the small rate of substitutions between $\mathrm{Ca}$ and $\mathrm{Sr}$. The heterogeneity of focal $\mathrm{Sr}$ distribution between bone formed before or during treatment observed in this study has also been reported in monkeys receiving SrRan $(33,34)$. Only recent bone formed during treatment took up $\mathrm{Sr}$ by ionic substitution within the apatite crystal lattice and by ionic exchange of $\mathrm{Ca}$ ions by $\mathrm{Sr}$ ions in the hydrated layer of the crystals $(33,35)$, but we were not able to measure in which proportions for each site of the crystal. Recently, it has been reported that, in goats receiving $40 \mathrm{mg} / \mathrm{kg}$ per day of Sr for 16 weeks, there was no change in the bone crystal morphology and structure, and a limited amount of Sr replaced Ca in apatite crystals (38). Another study on a very small number of patients receiving daily $2 \mathrm{~g}$ SrRan for 36 months (35) also confirmed that $\mathrm{Sr}$ preserved the thickness and the length of bone mineral crystals.

\section{Sr and mineralization of bone}

DMB and HI were constantly at a normal value in treated PMOP patients whatever the duration of the SrRan treatment. Moreover, DMB and HI values, from 36 to 60 months, were comparable to data from patients treated with placebo (Ca and vitamin D) for 36 months (32) (Fig. 4). Furthermore, the mean DMB from patients receiving a prolonged treatment was close to the mean DMB from controls, premenopausal women (23), and PMOP patients treated for 36 months with SrRan $(32,36)$. Moreover, these values are also 
comparable to untreated osteoporotic patients, with a mean DMB of $1.042 \pm 0.095$ and $1.084 \pm 0.092$ in cortical and cancellous bone respectively (29). These data have been recently confirmed in untreated postmenopausal patients (39). Thus, the secondary mineralization was not modified by $\mathrm{Sr}$ as previously reported in animals $(6,11,33-35)$ and human $(19,32)$ studies. However, we know that the presence of Sr ions, larger than Ca ions, leads to a greater attenuation of $\mathrm{X}$-rays. Thus, it remained possible that a decrease in $\mathrm{DMB}$ in recent bone was masked by the presence of $\mathrm{Sr}$ in bone, resulting in an unchanged DMB. SrRan increased bone formation and decreased bone resorption (1-5, 9, 24, 32). Indeed, in SrRan-treated PMOP women (19), the maintenance of the primary mineralization of bone (mineral apposition rate) has been shown in addition to a decrease in osteoid thickness and an increase in osteoblastic surfaces $(+38 \%$ in cancellous and endocortical bone). Finally, even in women receiving a prolonged SrRan treatment, a preservation of the normal bone secondary mineralization process was observed. This was also the case in monkeys treated with high doses of SrRan $(33,34)$ and in PMOP women treated for 36 months with $\operatorname{SrRan}(32,35,36)$.

\section{Conclusions}

In conclusion, during 60 months of treatment with SrRan, i) Sr was almost exclusively distributed in recent bone formed during the treatment; ii) the areas containing Sr increased during 60 months of treatment; iii) the $\mathrm{Sr}$ focal content in recent bone was constant at each time point; iv) whatever the duration of treatment and the content of $\mathrm{Sr}$ in bone, the secondary mineralization (density and heterogeneity at tissue level) was maintained within the normal range. Finally, after a prolonged treatment with SrRan, the quality of bone mineralization in PMOP women was unchanged.

\section{Declaration of interest}

P J Meunier and G Boivin serve as consultants for the Servier Company. All other authors have no conflicts of interest.

\section{Funding}

This study was supported by Servier (Courbevoie, France) and by Institut National de la Santé et de la Recherche Médicale. The expert technical assistance of Albert Perrat (Centre Technologique des Microstructures, Université de Lyon, Villeurbanne, France) was also gratefully appreciated.

\section{References}

1 Bonnelye E, Chabadel A, Saltel F \& Jurdic P. Dual effect of strontium ranelate: stimulation of osteoblast differentiation and inhibition of osteoclast formation and resorption in vitro. Bone $2008 \mathbf{4 2}$ 129-138. (doi:10.1016/j.bone.2007.08.043)
2 Canalis E, Hott M, Deloffre P, Tsouderos Y \& Marie PJ. The divalent strontium salt S12 911 enhances bone cell replication and bone formation in vitro. Bone 199618 517-523. (doi:10.1016/87563282(96)00080-4)

3 Takahashi N, Sasaki T, Tsouderos Y \& Suda T. S12 911-2 inhibits osteoclastic bone resorption in vitro. Journal of Bone and Mineral Research 200318 1082-1087. (doi:10.1359/jbmr.2003.18.6. 1082)

4 Barbara A, Delannoy P, Denis BG \& Marie PJ. Normal matrix mineralization induced by strontium ranelate in MC3T3-E1 osteogenic cells. Metabolism 200453 532-537. (doi:10.1016/j. metabol.2003.10.022)

5 Baron R \& Tsouderos Y. In vitro effects of S12 911-2 on osteoclast function and bone marrow macrophage differentiation. European Journal of Pharmacology 2002450 11-17. (doi:10.1016/S00142999(02)02040-X)

6 Buehler J, Chappuis P, Saffar JL, Tsouderos Y \& Vignery A. Strontium ranelate inhibits bone resorption while maintaining bone formation in alveolar bone in monkeys (Macaca fascicularis). вопе 200129 176-179. (doi:10.1016/S8756-3282(01)00 484-7)

7 Delannoy P, Bazot D \& Marie PJ. Long-term treatment with strontium ranelate increases vertebral bone mass without deleterious effect in mice. Metabolism $2002 \quad 51$ 906-911. (doi:10.1053/meta.2002.33360)

8 Hott M, Deloffre P, Tsouderos Y \& Marie PJ. S12 911-2 reduces bone loss induced by short-term immobilization in rats. Bone 2003 33 115-123. (doi:10.1016/S8756-3282(03)00115-7)

9 Marie PJ, Hott M, Modrowski D, De Pollak C, Guillemain J, Deloffre P \& Tsouderos Y. An uncoupling agent containing strontium prevents bone loss by depressing bone resorption and maintaining bone formation in estrogen-deficient rats. Journal of Bone and Mineral Research 19938 607-615. (doi:10.1002/jbmr. 5650080512)

10 Ammann P, Shen V, Robin B, Mauras Y, Bonjour JP \& Rizzoli R. Strontium ranelate improves bone resistance by increasing bone mass and improving architecture in intact female rats. Journal of Bone and Mineral Research 200419 2012-2020. (doi:10.1359/ jbmr.040906)

11 Ammann P, Badoud I, Barraud S, Dayer R \& Rizzoli R. Strontium ranelate treatment improves trabecular and cortical intrinsic bone tissue quality, a determinant of bone strength. Journal of Bone and Mineral Research 200722 1419-1425. (doi:10.1359/jbmr. 070607)

12 Bain SD, Jerome C, Shen V, Dupin-Roger I \& Ammann P. Strontium ranelate improves bone strength in ovariectomized rat by positively influencing bone resistance determinants. Osteoporosis International 200920 1417-1428. (doi:10.1007/s00198-0080815-8)

13 Marie PJ, Felsenberg D \& Brandi ML. How strontium ranelate, via opposite effects on bone resorption and formation, prevents osteoporosis. Osteoporosis International 201122 1659-1667. (doi:10.1007/s00198-010-1369-0)

14 Meunier PJ, Roux C, Ortolani S, Diaz-Curiel M, Compston J, Marquis P, Cormier C, Isaia G, Badurski J, Wark JD, Collette J \& Reginster JY. Effects of long-term strontium ranelate treatment on vertebral fracture risk in postmenopausal women with osteoporosis. Osteoporosis International 200920 1663-1673. (doi:10.1007/ s00198-008-0825-6)

15 Meunier PJ, Roux C, Seeman E, Ortolani S, Badurski JE, Spector TD, Cannata J, Balogh A, Lemmel EM, Pors-Nielsen S, Rizzoli R, Genant HK \& Reginster JY. The effects of strontium ranelate on the risk of vertebral fracture in women with postmenopausal osteoporosis. New England Journal of Medicine 2004350 459-468. (doi:10.1056/NEJMoa022436)

16 Meunier PJ, Slosman DO, Delmas PD, Sebert JL, Brandi ML, Albanese C, Lorenc R, Pors-Nielsen S, De Vernejoul MC, Roces A \& Reginster JY. Strontium ranelate: dose-dependent effects in established postmenopausal vertebral osteoporosis - a 2-year 
randomized placebo controlled trial. Journal of Clinical Endocrinology and Metabolism 200287 2060-2066. (doi:10. $1210 /$ jc. 87.5.2060)

17 Reginster JY, Bruyere O, Sawicki A, Roces-Varela A, Fardellone P, Roberts A \& Devogelaer JP. Long-term treatment of postmenopausal osteoporosis with strontium ranelate: results at 8 years. Bone 200945 1059-1064. (doi:10.1016/j.bone.2009.08.004)

18 Reginster JY, Seeman E, De Vernejoul MC, Adami S, Compston J, Phenekos C, Devogelaer JP, Curiel MD, Sawicki A, Goemaere S, Sorensen $\mathrm{OH}$, Felsenberg D \& Meunier PJ. Strontium ranelate reduces the risk of nonvertebral fractures in postmenopausal women with osteoporosis: Treatment of Peripheral Osteoporosis (TROPOS) study. Journal of Clinical Endocrinology and Metabolism 200590 2816-2822. (doi:10.1210/jc.2004-1774)

19 Arlot ME, Jiang Y, Genant HK, Zhao J, Burt-Pichat B, Roux JP, Delmas PD \& Meunier PJ. Histomorphometric and microCT analysis of bone biopsies from postmenopausal osteoporotic women treated with strontium ranelate. Journal of Bone and Mineral Research 200823 215-222. (doi:10.1359/jbmr.071012)

20 Hamdy NA. Strontium ranelate improves bone microarchitecture in osteoporosis. Rheumatology 200948 (Supplement 4) iv9-iv13. (doi:10.1093/rheumatology/kep274)

21 Rizzoli R, Laroche M, Krieg MA, Frieling I, Thomas T, Delmas P \& Felsenberg D. Strontium ranelate and alendronate have differing effects on distal tibia bone microstructure in women with osteoporosis. Rheumatology International 201030 1341-1348. (doi:10.1007/s00296-010-1542-y)

22 Bala Y, Farlay D, Delmas PD, Meunier PJ \& Boivin G. Time sequence of secondary mineralization and microhardness in cortical and cancellous bone from ewes. Bone $2010 \mathbf{4 6}$ 1204-1212. (doi:10.1016/j.bone.2009.11.032)

23 Boivin G, Bala Y, Doublier A, Farlay D, Ste-Marie LG, Meunier PJ \& Delmas PD. The role of mineralization and organic matrix in the microhardness of bone tissue from controls and osteoporotic patients. Bone 200843 532-538. (doi:10.1016/j.bone.2008. 05.024)

24 Boivin G, Farlay D, Bala Y, Doublier A, Meunier PJ \& Delmas PD. Influence of remodeling on the mineralization of bone tissue. Osteoporosis International 200920 1023-1026. (doi:10.1007/ s00198-009-0861-x)

25 Boivin G \& Meunier PJ. Changes in bone remodeling rate influence the degree of mineralization of bone. Connective Tissue Research 200243 535-537. (doi:10.1080/03008200290000934)

26 Boivin G \& Meunier PJ. The degree of mineralization of bone tissue measured by computerized quantitative contact microradiography. Calcified Tissue International 200270 503-511. (doi:10. 1007/s00223-001-2048-0)

27 Arlot M, Meunier PJ, Boivin G, Haddock L, Tamayo J, CorreaRotter R, Jasqui S, Donley DW, Dalsky GP, Martin JS \& Eriksen EF. Differential effects of teriparatide and alendronate on bone remodeling in postmenopausal women assessed by histomorphometric parameters. Journal of Bone and Mineral Research 200520 1244-1253. (doi:10.1359/JBMR.050309)

28 Misof BM, Roschger P, Cosman F, Kurland ES, Tesch W, Messmer P, Dempster DW, Nieves J, Shane E, Fratzl P, Klaushofer K, Bilezikian J \& Lindsay R. Effects of intermittent parathyroid hormone administration on bone mineralization density in iliac crest biopsies from patients with osteoporosis: a paired study before and after treatment. Journal of Clinical Endocrinology and Metabolism $2003 \quad 88$ 1150-1156. (doi:10.1210/jc.2002021988)
29 Boivin G, Lips P, Ott SM, Harper KD, Sarkar S, Pinette KV \& Meunier PJ. Contribution of raloxifene and calcium and vitamin D3 supplementation to the increase of the degree of mineralization of bone in postmenopausal women. Journal of Clinical Endocrinology and Metabolism 200388 4199-4205. (doi:10. 1210/jc.2002-022020)

30 Boivin G, Vedi S, Purdie DW, Compston JE \& Meunier PJ. Influence of estrogen therapy at conventional and high doses on the degree of mineralization of iliac bone tissue: a quantitative microradiographic analysis in postmenopausal women. Bone $2005 \mathbf{3 6}$ 562-567. (doi:10.1016/j.bone.2004.12.009)

31 Boivin GY, Chavassieux PM, Santora AC, Yates J \& Meunier PJ. Alendronate increases bone strength by increasing the mean degree of mineralization of bone tissue in osteoporotic women. Bone 200027 687-694. (doi:10.1016/S8756-3282(00)00376-8)

32 Boivin G, Farlay D, Khebbab MT, Jaurand X, Delmas PD \& Meunier PJ. In osteoporotic women treated with strontium ranelate, strontium is located in bone formed during treatment with a maintained degree of mineralization. Osteoporosis International 201021 667-677. (doi:10.1007/s00198-0091005-z)

33 Boivin G, Deloffre P, Perrat B, Panczer G, Boudeulle M, Mauras Y, Allain P, Tsouderos Y \& Meunier PJ. Strontium distribution and interactions with bone mineral in monkey iliac bone after strontium salt (S12 911) administration. Journal of Bone and Mineral Research 199611 1302-1311. (doi:10.1002/jbmr. 5650110915)

34 Farlay D, Boivin G, Panczer G, Lalande A \& Meunier PJ. Long-term strontium ranelate administration in monkeys preserves characteristics of bone mineral crystals and degree of mineralization of bone. Journal of Bone and Mineral Research 200520 1569-1578. (doi:10.1359/JBMR.050405)

35 Li C, Paris O, Siegel S, Roschger P, Paschalis EP, Klaushofer K \& Fratzl P. Strontium is incorporated into mineral crystals only in newly formed bone during strontium ranelate treatment. Journal of Bone and Mineral Research 201025 968-975. (doi:10.1359/jbmr. 091038)

36 Roschger P, Manjubala I, Zoeger N, Meirer F, Simon R, Li C, FratzlZelman N, Misof BM, Paschalis EP, Streli C, Fratzl P \& Klaushofer K. Bone material quality in transiliac bone biopsies of postmenopausal osteoporotic women after 3 years of strontium ranelate treatment. Journal of Bone and Mineral Research 201025 891-900. (doi:10.1359/jbmr.090702)

37 Basle MF, Mauras Y, Audran M, Clochon P, Rebel A \& Allain P. Concentration of bone elements in osteoporosis. Journal of Bone and Mineral Research 19905 41-47. (doi:10.1002/jbmr.56500 50108)

38 Li Z, Lu WW, Deng L, Chiu PK, Fang D, Lam RW, Leong JC \& Luk KD. The morphology and lattice structure of bone crystal after strontium treatment in goats. Journal of Bone and Mineral Metabolism 201028 25-34. (doi:10.1007/s00774-009-0109-z)

39 Bala Y, Bare S, Boivin G \& Recker RR. Bone tissue quality in the years after menopause: micro-hardness is decreased independently of changes in the degree of mineralization. Journal of Bone and Mineral Research 201025 (Supplement 1). In ASBMR. Toronto, Canada.

Received 14 June 2011

Accepted 20 June 2011 